\title{
Effect of thioridazine on antioxidant status of HEMn-DP melanocytes
}

\author{
Michal Otrẹba $^{1}$ - Artur Beberok ${ }^{1}$ - Dorota Wrześniok ${ }^{1}$. \\ Jakub Rok ${ }^{1} \cdot$ Ewa Buszman ${ }^{1}$
}

Received: 2 February 2015 / Accepted: 5 June 2015 /Published online: 24 June 2015

(C) The Author(s) 2015. This article is published with open access at Springerlink.com

\begin{abstract}
Thioridazine as an antipsychotic agent was extensively used to treat various psychotic disorders, e.g. schizophrenia. However, the therapy with this drug can induce serious side effects such as extrapyramidal symptoms or ocular and skin disorders, which mechanisms are still not fully established. To gain inside the molecular mechanisms underlying thioridazine toxicity, we examined the effect of this drug on cell viability, antioxidant defence system as well as melanogenesis in normal human melanocytes. It was demonstrated that thioridazine induces concentration-dependent loss in cell viability. The value of $\mathrm{EC}_{50}$ was calculated to be $2.24 \mu \mathrm{M}$. To study the effect of thioridazine on antioxidant defence system in melanocytes, the level of hydrogen peroxide and the activities of antioxidant enzymes superoxide dismutase, catalase and glutathione peroxidase were determined. The drug in concentrations of $0.1,0.25,1.0$ and $2.5 \mu \mathrm{M}$ caused changes in cellular antioxidant defence system indicating the induction of oxidative stress. It was also shown that the analysed neuroleptic in concentrations of 1.0 and $2.5 \mu \mathrm{M}$ significantly inhibited melanogenesis. The observed changes in cell viability, antioxidant defence system and melanization in normal human melanocytes after thioridazine treatment may explain an important role of reactive oxygen species as well as melanin in mechanisms involved in this drug side effects directed on pigmented tissues.
\end{abstract}

Ewa Buszman

ebuszman@sum.edu.pl

1 Department of Pharmaceutical Chemistry, School of Pharmacy with the Division of Laboratory Medicine in Sosnowiec, Medical

University of Silesia in Katowice, Jagiellońska 4, PL

41-200 Sosnowiec, Poland
Keywords Thioridazine $\cdot$ Melanocytes $\cdot$ Antioxidant enzymes $\cdot$ Hydrogen peroxide

\section{Introduction}

Thioridazine is a typical antipsychotic drug belonging to phenothiazine neuroleptics of the piperidine type. It is a mild neuroleptic, displaying sedative and antidepressant effects, which was used in the treatment of positive and negative symptoms of schizophrenia (Wójcikowski et al. 2006). Because of the fact that thioridazine treatment is associated with prolongation of the QT interval, this agent was withdrawn from the market (Buj Alvarez et al. 2007). Thioridazine also exhibits anticancer, antibacterial, antiviral, antiprotozoic as well as multidrug resistance reversal activity (Morak-Młodawska and Jeleń 2007; Rho et al. 2011). Anticancer activity of this drug results from its antiproliferative and antisurvival effects (Min et al. 2014). Thioridazine increased apoptosis in melanoma (Gil-Ad et al. 2004), endometrial (Kang et al. 2012), ovarian (Rho et al. 2011) and lymphoma (Nagel et al. 2012) cells. Due to the fact that thioridazine is a subject of many novel studies, it is important to explain molecular mechanisms underlying these drug adverse effects directed to pigmented tissues such as skin disorders, e.g. maculopapular rash, erythema multiforme, contact dermatitis, generalized urticaria, pigmentation changes and photoinduced lichenoid reaction (Arana 2000; MacMorran and Krahn 1997). It has been reported that thioridazine photosensitivity is less common than chlorpromazine but as other phenothiazine derivatives may lead to retinal pigment epithelium (RPE) damage (Drucker and Rosen 2011; Hu et al. 2002; Llambrich and Lecha 2004). The skin photosensitivity reactions are primarily seen in sun-exposed areas of the face, neck, upper chest, dorsum of the hand and lower legs and begin with a tan or brownish discoloration that progresses to a purple or slate-like metallic blue. Pigmentation changes occur 
usually after a long-term and/or high-dose use of phenothiazines such as chlorpromazine or thioridazine (MacMorran and Krahn 1997). Pigmentation disorders of the skin can be either hypomelanotic or hypermelanotic or may be present with a pattern of mixed hypo- and hypermelanosis (Lamer et al. 2010). The skin disorders suggest a potential role of endogenous melanin in the induction of these side effects in pigmented tissues.

Melanocytes are highly specialized cells that are not only found in the skin or eyes but are also present in the hair, inner ear, brain, lungs, heart and adipose tissue, where they produce melanin (Plonka et al. 2009; Rok et al. 2012; Tolleson 2005). The cellular antioxidant system, the first line of defence against oxidative stress, includes a number of antioxidant enzymes, such as superoxide dismutase (SOD), catalase (CAT) and glutathione peroxidase (GPx). It has been demonstrated that melanins possess superoxide dismutase activity and are able to remove reactive oxygen species (ROS), and thus may protect pigmented tissues against cellular damage (autocatalytic lipid peroxidation of membranes, lesions in DNA, cross-linkage in proteins) induced by oxidative stress (Bickers and Athar 2006; Hoogduijn et al. 2004; Otręba et al. 2012; Singh et al. 2009; Wakamatsu et al. 2008).

Previously, we have documented that another neurolepticchlorpromazine (Otręba et al. 2015), as well as aminoglycoside antibiotics (Wrześniok et al. 2013a,b,c), and fluoroquinolone antibiotics (Beberok et al. 2012) induce oxidative stress in normal human melanocytes, which may be a reason for many disorders.

The aim of this study was to examine the effect of thioridazine on cell viability, antioxidant defence system as well as melanogenesis in normal human melanocytes dark pigmented (HEMn-DP).

\section{Materials and methods}

\section{Materials}

Thioridazine hydrochloride, phosphate-buffered saline (PBS), 3,4-dihydroxy-L-phenylalanine (L-DOPA) and amphotericin B were purchased from Sigma-Aldrich Inc. (USA). Neomycin sulphate was obtained from Amara (Poland). Penicillin was acquired from Polfa Tarchomin (Poland). Growth medium M254 and human melanocyte growth supplement-2 (HMGS-2) were obtained from Cascade Biologics (UK). Trypsin/EDTA was obtained from Cytogen (Poland). Cell Proliferation Reagent WST-1 (4-[3-(4-iodophenyl)-2-(4-nitrophenyl)-2H-5tetrazolio]-1,3-benzene disulphonate) was purchased from Roche GmbH (Germany). The remaining chemicals were produced by POCH S.A. (Poland).

\section{Cell culture}

The normal human epidermal melanocytes (HEMn-DP; Cascade Biologics) were grown according to the manufacturer's instruction. The cells were cultured in M-254 basal medium supplemented with HMGS-2, penicillin (100 U/ml), neomycin $(10 \mu \mathrm{g} / \mathrm{ml})$ and amphotericin $\mathrm{B}(0.25 \mu \mathrm{g} / \mathrm{ml})$ at $37{ }^{\circ} \mathrm{C}$ in $5 \% \mathrm{CO}_{2}$. All experiments were performed using cells in the passages 6-9.

\section{Cell viability assay}

The viability of melanocytes was evaluated by the WST-1 (4-[3-(4-iodophenyl)-2-(4-nitrophenyl)-2H-5-tetrazolio]-1,3benzene disulphonate) colorimetric assay. WST-1 is a watersoluble tetrazolium salt; the rate of WST-1 cleavage by mitochondrial dehydrogenases correlates with the number of viable cells. In brief, 5000 cells per well were placed in a 96-well microplate in a supplemented M-254 growth medium and incubated at $37{ }^{\circ} \mathrm{C}$ and $5 \% \mathrm{CO}_{2}$ for $48 \mathrm{~h}$. Then the medium was removed and cells were treated with thioridazine solutions in a concentration range from 0.0001 to $10 \mu \mathrm{M}$. After 21-h incubation, $10 \mu \mathrm{l}$ of WST-1 were added to $100 \mu \mathrm{l}$ of culture medium in each well, and the incubation was continued for $3 \mathrm{~h}$. The absorbance of the samples was measured at $440 \mathrm{~nm}$ with a reference wavelength of $650 \mathrm{~nm}$, against the controls (the same cells but not treated with thioridazine) using a microplate reader UVM 340 (Biogenet, Poland). The controls were normalized to $100 \%$ for each assay and treatments were expressed as the percentage of the controls.

\section{SOD assay}

Superoxide dismutase (SOD) activity was measured using an assay kit (Cayman, MI, USA) according to the manufacturer's instruction. This kit utilizes a tetrazolium salt for the detection of superoxide radicals generated by xanthine oxidase and hypoxanthine. One unit of SOD was defined as the amount of enzyme needed to produce $50 \%$ dismutation of superoxide radical. SOD activity was expressed in units per milligram protein.

\section{CAT assay}

Catalase (CAT) activity was measured using an assay kit (Cayman, MI, USA) according to the manufacturer's instruction. This kit utilizes the peroxidatic function of CAT for determination of enzyme activity. The method is based on the reaction of the enzyme with methanol in the presence of an optimal concentration of hydrogen peroxide $\left(\mathrm{H}_{2} \mathrm{O}_{2}\right)$. The formaldehyde produced is measured colorimetrically with 4amino-3-hydrazino-5-mercapto-1,2,4-triazole (Purpald) as the chromogen. One unit of CAT was defined as the amount of enzyme that causes the formation of $1.0 \mathrm{nmol}$ of formaldehyde per minute at $25{ }^{\circ} \mathrm{C}$. CAT activity was expressed in nanomole per minute per milligram protein. 


\section{GPx assay}

GPx activity was measured using an assay kit (Cayman, MI, USA) according to the manufacturer's instruction. The measurement of GPx activity is based on the principle of a coupled reaction with glutathione reductase (GR). The oxidized glutathione (GSSG) formed after reduction of hydroperoxide by GPx is recycled to its reduced state (GSH) by GR in the presence of NADPH. The oxidation of NADPH is accompanied by a decrease in absorbance at $340 \mathrm{~nm}$. One unit of GPx was defined as the amount of enzyme that catalyses the oxidation of $1 \mathrm{nmol}$ of NADPH per minute at $25^{\circ} \mathrm{C}$. GPx activity was expressed in nanomole per minute per milligram protein.

\section{$\mathrm{H}_{2} \mathrm{O}_{2}$ assay}

$\mathrm{H}_{2} \mathrm{O}_{2}$ content was measured using an assay kit (Cell Biolabs, Inc., USA) according to the manufacturer's instruction. This method is based on the ability of sorbitol to convert peroxide to a peroxyl radical, which oxidizes $\mathrm{Fe}^{2+}$ into $\mathrm{Fe}^{3+}$. Then $\mathrm{Fe}^{3+}$ reacts with an equimolar amount of xylenol orange in the presence of acid to create a purple product that absorbs light at maximal wavelength $595 \mathrm{~nm}$. The antioxidant-butylated hydroxytoluene (BHT) - is provided to prevent further undesirable chain peroxidation. Hydrogen peroxide content in the samples was expressed in micromole per milligram protein.

\section{Measurement of melanin content}

The melanocytes were seeded in T-25 flasks at a density of $1 \times$ $10^{5}$ cells per flask. Thioridazine treatment in a concentration range from 0.01 to $2.5 \mu \mathrm{M}$ began $48 \mathrm{~h}$ after seeding. After $24 \mathrm{~h}$ of incubation, melanocytes were washed three times with PBS and viable cells were detached with trypsin-EDTA. Cell pellets were placed into Eppendorf tubes, dissolved in $100 \mu \mathrm{l}$ of $1 \mathrm{M} \mathrm{NaOH}$ at $80^{\circ} \mathrm{C}$ for $1 \mathrm{~h}$ and then centrifuged for $20 \mathrm{~min}$ at $16,000 \mathrm{~g}$. The supernatants were placed into a 96-well microplate, and absorbance was measured at $405 \mathrm{~nm}$ - a wavelength at which melanin absorbs light (Ozeki et al. 1996). A standard synthetic melanin curve (0 to $400 \mu \mathrm{g} / \mathrm{ml})$ was performed in triplicate for each experiment. Melanin content in thioridazine treated cells was expressed as the percentage of the controls (untreated melanocytes).

\section{Tyrosinase activity assay}

Tyrosinase activity in HEMn-DP cells was determined by measuring the rate of oxidation of L-DOPA to DOPAchrome, according to the method described by Kim et al. (2005) and Busca et al. (1996), with a slight modification. The cells were cultured at a density of $1 \times 10^{5}$ cells in T25 flasks for $48 \mathrm{~h}$. After 24-h incubation with thioridazine (concentration range from 0.01 to $2.5 \mu \mathrm{M}$ ), cells were washed three times with PBS, lysed and clarified by centrifugation at $10,000 \mathrm{~g}$ for $5 \mathrm{~min}$. A tyrosinase substrate L-DOPA $(2 \mathrm{mg} / \mathrm{ml})$ was prepared in the same lysis phosphate buffer. One hundred microlitres of each lysate were put in a 96-well plate, and the enzymatic assay was initiated by the addition of $40 \mu \mathrm{l}$ of $\mathrm{L}$ DOPA solution at $37{ }^{\circ} \mathrm{C}$. Absorbance was measured every $10 \mathrm{~min}$ for at least $1.5 \mathrm{~h}$ at $475 \mathrm{~nm}$ using a microplate reader. Tyrosinase activity was expressed as the percentage of the controls (untreated melanocytes).

\section{MITF assay}

Microphthalmia-associated transcription factor (MITF) content was measured using ELISA, an assay kit (USCN Life Science Inc, USA), according to the manufacturer's instruction. This kit is a sandwich enzyme immunoassay for in vitro quantitative measurement of MITF providing a 96-well microplate pre-coated with a biotin-conjugated antibody specific for MITF. The colour change of the enzyme (horseradish peroxidase)-substrate (TMB) reaction was measured spectrophotometrically at $450 \mathrm{~nm}$ using a microplate reader. MITF content in the samples was expressed as the percentage of the controls (untreated melanocytes).

\section{Statistical analysis}

In all experiments, mean values of at least three separate experiments $(n=3)$ performed in triplicate \pm standard deviation (SD) were calculated. Statistical analysis was performed with one-way ANOVA followed by Tukey post-hoc test using GraphPad Prism 6.01 software. The significance level was

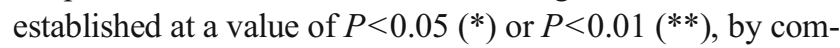
paring the data with those for control (cells without thioridazine).

\section{Results}

\section{The effect of thioridazine on cell viability}

The cell viability was determined by the WST-1 test after 24-h incubation with thioridazine in a concentration range from 0.0001 to $10 \mu \mathrm{M}$. It has been demonstrated that the analysed drug induces concentration-dependent loss in cell viability (Fig. 1). Melanocytes treated with 1.0, 2.5, 5.0, 7.5 and $10 \mu \mathrm{M}$ of thioridazine for $24 \mathrm{~h}$ lost $14.3,50.2,89.2,96.7$ and $99.1 \%$ in cell viability, respectively. The value of $\mathrm{EC}_{50}$ (the concentration of a drug that produces loss in cell viability by $50 \%$ ) was calculated to be $2.24 \mu \mathrm{M}$. At lower drug concentrations $(0.0001,0.001,0.01$ and $0.1 \mu \mathrm{M})$, the loss in melanocytes viability was not observed. 


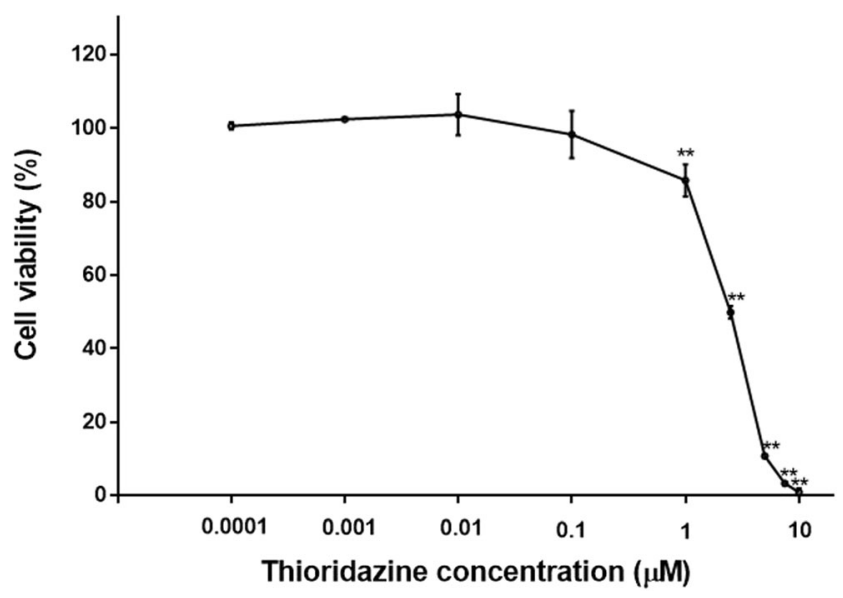

Fig. 1 The effect of thioridazine on viability of melanocytes. Cells were treated with various doses of thioridazine $(0.0001-10 \mu \mathrm{M})$ and examined by WST-1 assay. Data are expressed as percentage of cell viability. Mean values \pm SD from three independent experiments performed in triplicate are presented. $* * P<0.01$ vs. the control samples

\section{The effect of thioridazine on antioxidant defence system in melanocytes}

To study the effect of thioridazine on reactive oxygen species metabolism in melanocytes, the activity of antioxidant enzymes and the content of hydrogen peroxide were determined. Cells were exposed to thioridazine in concentrations of 0.01 , $0.025,0.1,0.25,1.0$ and $2.5 \mu \mathrm{M}$ for $24 \mathrm{~h}$.

Thioridazine raised SOD activity (Fig. 2a). After performing a calibration curve, the SOD activity was determined as 0.82 to $1.19 \mathrm{U} / \mathrm{mg}$ protein for melanocytes treated with a drug and $0.78 \pm 0.06 \mathrm{U} / \mathrm{mg}$ protein for a control sample. The treatment of cells with $0.1,0.25,1.0$ and $2.5 \mu \mathrm{M}$ of thioridazine increased the SOD activity by 12.5, 23.9, 33.1 and $52.6 \%$, respectively, as compared with the controls. The analysed drug in concentrations of 0.01 and $0.025 \mu \mathrm{M}$ had no impact on SOD activity.

After 24-h incubation with thioridazine, the intracellular CAT activity decreased (Fig. 2b). After performing a calibration curve, the CAT activity was determined as 18.45 to $24.98 \mathrm{nmol} / \mathrm{min} / \mathrm{mg}$ protein for melanocytes treated with a drug and $23.62 \pm 0.48 \mathrm{nmol} / \mathrm{min} / \mathrm{mg}$ protein for a control sample. Treatment of HEMn-DP cells with thioridazine in concentrations of $0.1,0.25,1.0$ and $2.5 \mu \mathrm{M}$ decreased enzyme activity by $9.0,12.3,14.4$ and $21.9 \%$, respectively. Thioridazine in concentrations of 0.01 and $0.025 \mu \mathrm{M}$ had no impact on CAT activity.

The analysed drug modified GPx activity in melanocytes (Fig. 2c). After performing a calibration curve, the GPx activity was determined as 14.60 to $17.87 \mathrm{nmol} / \mathrm{min} / \mathrm{mg}$ protein for cells treated with thioridazine and $16.89 \pm 0.44 \mathrm{nmol} / \mathrm{min} / \mathrm{mg}$ protein for a control sample. Treatment of melanocytes with $0.1 \mu \mathrm{M}$ of a drug caused small increase (by $5.8 \%$ ) in GPx activity, while the concentrations 1.0 and $2.5 \mu \mathrm{M}$ decreased the enzyme activity by 7.4 and $13.6 \%$, respectively. Thioridazine in concentrations of $0.01,0.025$ and $0.25 \mu \mathrm{M}$ had no impact on GPx activity in comparison with the controls.

After 24-h incubation of melanocytes with thioridazine, the hydrogen peroxide $\left(\mathrm{H}_{2} \mathrm{O}_{2}\right)$ content increased in a concentration-dependent manner (Fig. 2d). The $\mathrm{H}_{2} \mathrm{O}_{2}$ content was determined as 166.10 to $252.64 \mu \mathrm{mol} / \mathrm{mg}$ protein for melanocytes treated with a drug and $151.28 \pm 5.92 \mu \mathrm{mol} / \mathrm{mg}$ protein for a control sample. The treatment of cells with 0.01 , $0.025,0.1,0.25,1.0$ and $2.5 \mu \mathrm{M}$ of thioridazine increased the $\mathrm{H}_{2} \mathrm{O}_{2}$ content by $9.8,26.9,44.2,49.4,51.7$ and $67.0 \%$, respectively, as compared with the controls.

\section{The effect of thioridazine on melanization process}

The effectiveness of melanization process was estimated by measuring the melanin content, cellular tyrosinase activity and microphthalmia-associated transcription factor (MITF) content in melanocytes treated with $0.01,0.025,0.1,0.25,1.0$ and $2.5 \mu \mathrm{M}$ of thioridazine for $24 \mathrm{~h}$. After determining a calibration curve, the melanin content per cell was determined as 53.5 to $63.6 \mathrm{pg} / \mathrm{cell}$ for melanocytes treated with the analysed drug and $61.2 \pm 2.39 \mathrm{pg} / \mathrm{cell}$ for a control sample. The obtained results, recalculated for culture $\left(1 \times 10^{5}\right.$ cells $)$, were finally expressed as a percentage of the controls (Fig. 3a). Treatment of HEMn-DP cells with 1.0 and $2.5 \mu \mathrm{M}$ of a drug caused decrease in melanin content by 7.4 and $12.6 \%$, respectively. Thioridazine in concentrations from 0.01 to $0.25 \mu \mathrm{M}$ had no impact on melanin content in melanocytes.

Tyrosinase activity in melanocytes treated with thioridazine decreased in a manner correlating well with the effect on melanin production (Fig. 3b). The enzyme activity was determined as 0.85 to $1.03 \mu \mathrm{mol} / \mathrm{min} / \mathrm{mg}$ protein for melanocytes treated with thioridazine and $0.98 \pm 0.02 \mu \mathrm{mol} / \mathrm{min} / \mathrm{mg}$ for a control sample. The tyrosinase activity was decreased by 6.5 and $13.7 \%$ for cells treated with a drug in concentrations of 1.0 and $2.5 \mu \mathrm{M}$, respectively, as compared with the controls. Thioridazine in concentrations from 0.01 to $0.25 \mu \mathrm{M}$ had no impact on cellular tyrosinase activity.

After performing a calibration curve, the MITF content was determined as 0.18 to $0.26 \mathrm{ng} / \mathrm{mg}$ protein for melanocytes treated with a drug and $0.26 \pm 0.01 \mathrm{ng} / \mathrm{mg}$ protein for a control sample (Fig. 3c). Treatment of HEMn-DP cells with thioridazine in concentrations of $0.25,1.0$ and $2.5 \mu \mathrm{M}$ decreased MITF content by $12.7,28.7$ and $31.3 \%$, respectively. Thioridazine in concentrations from 0.01 to $0.1 \mu \mathrm{M}$ had no impact on the cellular MITF content in comparison to the control cells.

\section{Discussion}

Human skin is a major target for oxidative stress because of constant exposure to high levels of ROS produced by 
Fig. 2 Superoxide dismutase (SOD) (a), catalase (CAT) (b) and glutathione peroxidase (GPx) (c) activities and hydrogen peroxide $\left(\mathrm{H}_{2} \mathrm{O}_{2}\right)$ content $(\mathbf{d})$ in HEMn-DP cells after 24-h incubation with $0.01,0.025,0.1,0.25,1.0$ or $2.5 \mu \mathrm{M}$ of thioridazine. Data are mean \pm SD from at least three independent experiments performed in triplicate. ${ }^{*} P<0.05$ vs. the control samples; $* * P<0.01$ vs. the control samples
A

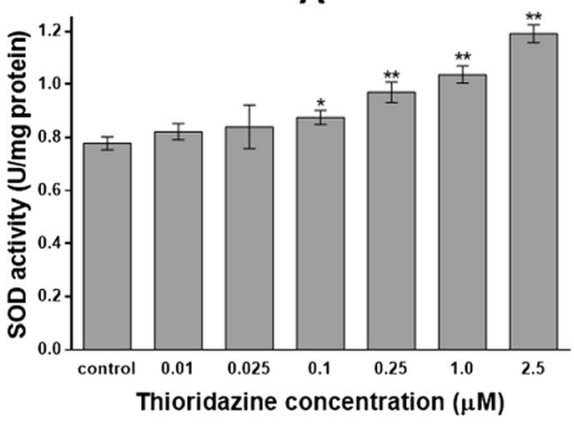

C

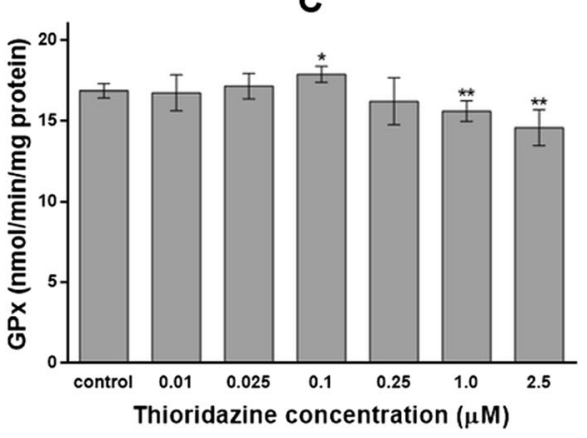

B

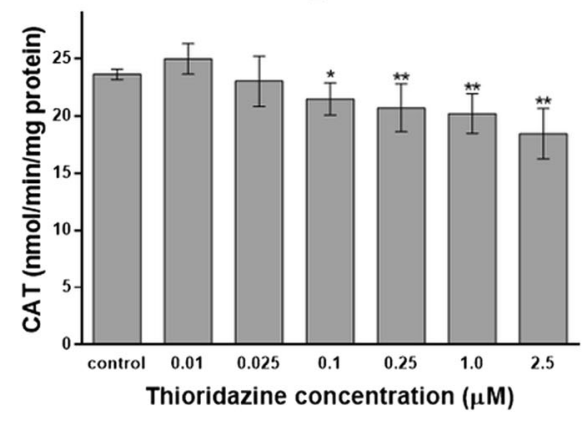

D

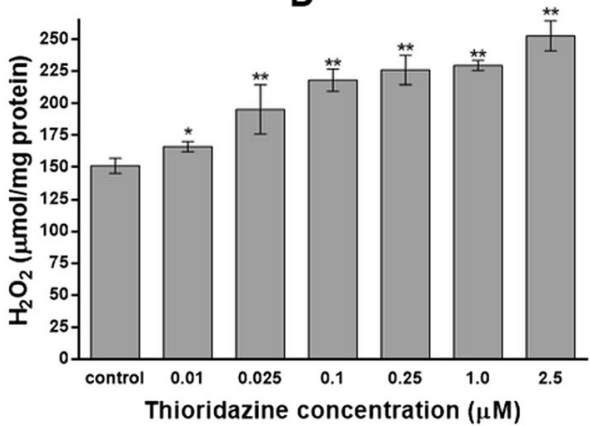

physical, chemical and biological reactions. Under normal conditions, various antioxidant enzymes, such as SOD, GPx and CAT, protect cells from the oxidative injury (Frey et al. 2007; Kalyanaraman 2013; Schallreuter et al. 2012). Melanocytes are especially sensitive to reactive oxygen species because of the low level of main enzyme responsible for degrading hydrogen peroxide - catalase (Schallreuter et al. 2008; Kim and Lee 2013). Under pathological conditions, oxidative stress arises from a serious imbalance between the free radicals and antioxidants levels and leads to modification and/or damage of lipids, proteins and DNA and thereby contributes to cellular dysfunction. Increased production of ROS after exposure to drugs and/or toxins has been linked with several major diseases such as cancer, diabetes, schizophrenia and neurodegenerative disorders (Frey et al. 2007; Kalyanaraman 2013; Mattila et al. 2007).

It is of interest that accumulation of $\mathrm{H}_{2} \mathrm{O}_{2}$ in melanocytes in millimolar concentrations may lead to disruption of many proteins and peptides leading to deactivation of important antioxidant enzymes including catalase, thioredoxin reductase and methionine sulphoxide reductases A and B (Schallreuter et al. 2008; Kim and Lee 2013). Sravani et al. (2009) demonstrated that high SOD levels and low levels of CAT in the skin of vitiligo patients are associated with oxidative stress in the pathogenesis of vitiligo. On the other hand, the micromolar concentrations of $\mathrm{H}_{2} \mathrm{O}_{2}$ cause an increase in the activity of many proteins and peptides such as tyrosinase, transcription factors (e.g. MITF, p53) as well as antioxidant enzymes (Schallreuter et al. 2008).
The aim of the present study was to investigate the effect of thioridazine on the antioxidant defence system and melanin formation in HEMn-DP melanocytes. In this study, we have used the culture of normal human epidermal melanocytes as an in vitro experimental model system.

Analysis of the effect of thioridazine on antioxidant status of HEMn-DP melanocytes demonstrated that this drug in concentrations of $0.1,0.25,1.0$ and $2.5 \mu \mathrm{M}$ significantly increased SOD activity and decreased CAT activity (Fig. 2a, b). The observed increase in SOD activity correlates well with the elevated level of $\mathrm{H}_{2} \mathrm{O}_{2}$ (Fig. 2d). The tested drug exerted a different effect on GPx activity (Fig. 2c). Thioridazine in concentration of $0.1 \mu \mathrm{M}$ increased activity of this enzyme in comparison to 1.0 and $2.5 \mu \mathrm{M}$ drug concentration, when decrease in GPx activity was observed. The presented decrease in CAT and GPx activity at higher drug concentrations (1.0 and $2.5 \mu \mathrm{M})$ may be connected with redundant cellular $\mathrm{H}_{2} \mathrm{O}_{2}$ level that cannot be eliminated. The activities of antioxidant enzymes and the content of $\mathrm{H}_{2} \mathrm{O}_{2}$ in melanocytes were normalized to viable cells which suggests that the observed changes in cellular antioxidant status may be caused by the reduced enzymes expression. Moreover, the disturbances of antioxidant defence system in melanocytes may result from the antagonistic effect of thioridazine on $\mathrm{D}_{2}$ receptors (Cuevas et al. 2013). Activation of dopamine $\mathrm{D}_{2}$ receptors regulates the production of reactive oxygen species by inhibiting prooxidant (NADPH oxidase) and stimulating antioxidant (CAT and SOD) enzyme activity (Cuevas et al. 2013; Iida et al. 1999). Thioridazine, which acts as a $D_{2}$ receptor antagonist (Beaulieu and Gainetdinov 2011), can induce oxidative stress 


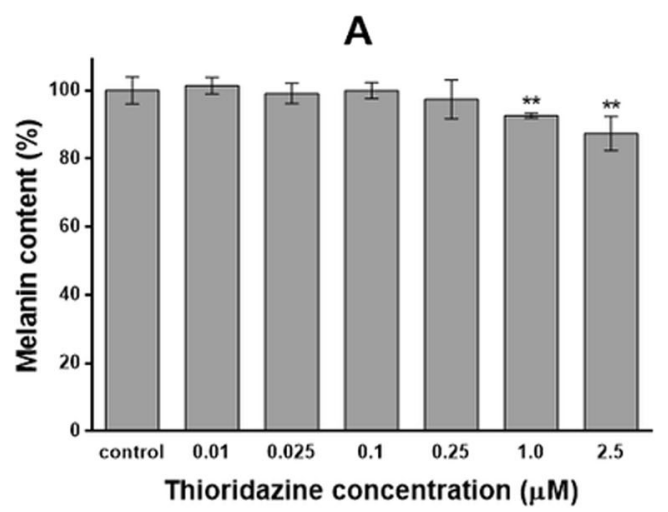

B
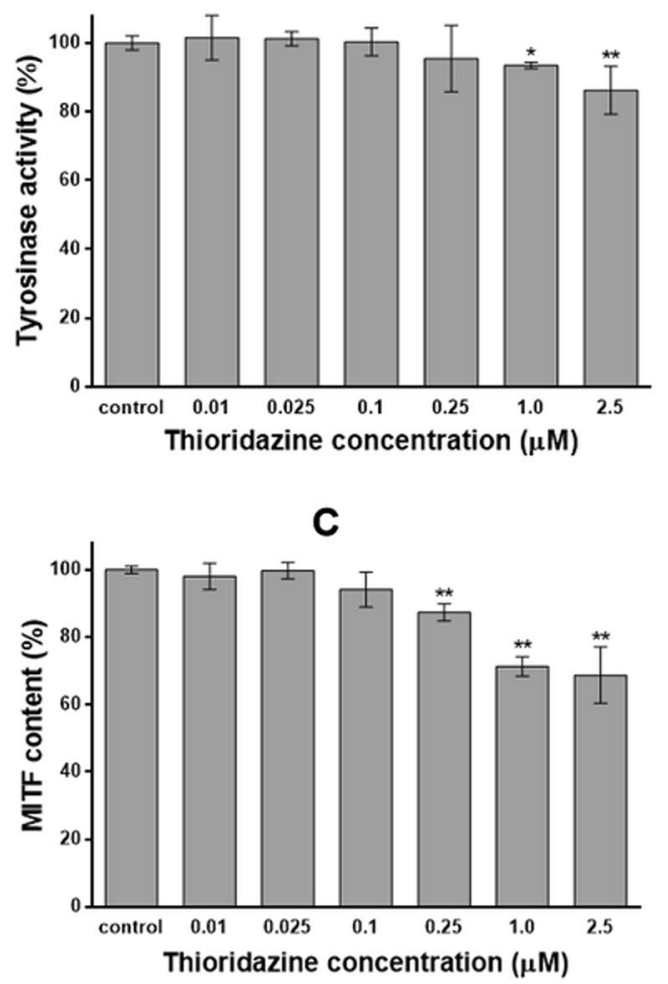

Fig. 3 The effect of thioridazine on melanin content (a), tyrosinase activity (b) and microphthalmia-associated transcription factor (MITF) content (c) in melanocytes. Cells were cultured with 0.01, 0.025, 0.1, $0.25,1.0$ or $2.5 \mu \mathrm{M}$ of thioridazine for $24 \mathrm{~h}$. Data are mean $\pm \mathrm{SD}$ from at least three independent experiments performed in triplicate. $* P<0.05$ vs. the control samples; $* * P<0.01$ vs. the control samples

in cells. The thioridazine-induced generation of reactive oxygen species and changes in SOD and CAT activities were also stated by other authors (Rukmini et al. 2004). It was shown that thioridazine and chlorpromazine evoked oxidative stress in serum of schizophrenia patients in whom the increase of SOD and CAT activity was observed.

Because of the fact that melanin may act as a scavenger of free radicals, we have examined the effect of thioridazine on melanogenesis process. Melanogenesis is a complex, multistage biochemical pathway responsible for brownish-black eumelanins and/or reddish-yellow pheomelanin synthesis. It takes place in melanocytes, in separate cytoplasmic organelles, called melanosomes. The key regulatory and ratelimiting melanogenic enzyme is tyrosinase, which is able to catalyse the first two steps of melanogenesis: the hydroxylation of L-tyrosine and the subsequent oxidation of the intermediate L-3,4-dihydroxyphenylalanine (L-DOPA) to yield LDOPAquinone (Hearing 2011; Liu et al. 2010; Otręba et al. 2012; Schallreuter et al. 2008). A large number of signal molecules and transcription factors regulate melanogenesis, but the major transcription factor is microphthalmia-associated transcription factor (MITF). The gene expression of main enzymes regulating melanogenesis (tyrosinase, TRP1, TRP2), cell survival, proliferation and differentiation is regulated by MITF (Kim et al. 2013; Otręba et al. 2012; Otręba et al. 2013).

The analysis of melanogenesis process in cells cultured in the presence of thioridazine demonstrates that this drug in concentrations of 1.0 and $2.5 \mu \mathrm{M}$ decreases tyrosinase activity as well as melanin content (Fig. 3a, b). Moreover, after melanocyte treatment with thioridazine in concentrations of 0.25 , 1.0 and $2.5 \mu \mathrm{M}$, the decrease in MITF content (Fig. 3c) was stated, which confirms the ability of this drug to inhibit melanogenesis in HEMn-DP melanocytes.

It is of interest that thioridazine has antagonistic properties for serotonin (5-HT) and dopamine (D) receptors that might be implicated in melanocyte biology. Immunocytochemical analysis of skin biopsies revealed that tryptophan hydroxylase (THP) and serotonin (5-HT) are localized primarily in normal melanocytes and in malignant melanoma cells, suggesting that the pathway for 5-HT synthesis is expressed predominantly in the melanotic cells. Serotonin can interact with specific cell surface membrane-bound receptors coupled with $G$ proteins. 5-HT1A receptor expression was demonstrated in the basal epidermal melanocytes, 5-HT2A receptors in the epidermis of normal and eczematous human skin and 5-HT3 in the proliferative basal layer of the epidermis (Nordlind et al. 2008; Lundeberg et al. 2002). 5-HT7 receptors can stimulate and 5HT1A receptors can attenuate adenylate cyclase activity, resulting in reducing and increasing of cyclic AMP level. Due to the fact that antagonists of 5-HT receptors may decrease the cAMP level, the reduction in expression of TYR and MITF genes may be observed (Nordlind et al. 2008; Otreba et al. 2012). Dopamine receptors are localized in the basal layer of the epidermis where they play an important role in the regulation of cell proliferation. The antagonists of $\mathrm{D}_{2}$ receptors reduce the cAMP level (Schallreuter et al. 2008; Slominski et al. 2012). Thus, the pharmacological properties of thioridazine with respect to its possibility to receptor binding in melanocytes should be taken into consideration in the elucidation of molecular mechanisms of thioridazine side effects in vivo. Taking into account the data published by Richtand et al. (2007) concerning the $K_{i}$ values of dopamine and serotonin receptor binding affinity for thioridazine $\left(K_{i}\right.$ from 10 to $579 \mathrm{nM}$ ), it may be suggested that the analysed 
drug is able to $\mathrm{D}_{2}$ dopamine and 5-HT receptor binding in all thioridazine concentrations (from 0.01 to $2.5 \mu \mathrm{M}$, i.e. from 10 to $2500 \mathrm{nM}$ ) used in this study.

Our earlier study showed that another phenothiazine derivative, namely chlorpromazine, in lower concentrations induced melanogenesis, while changes of antioxidant status were not observed (Otreba et al. 2015). The use of that drug in higher concentrations caused similar to thioridazine significant alterations of antioxidant enzyme activity in normal melanocytes.

The present work provides the first in vitro study on the mechanisms involved in thioridazine-induced oxidative stress and pigmentation disorders using HEMn-DP cells. The obtained results may explain a potential role of thioridazine in the depletion of cellular antioxidant status leading to hypopigmentation. Our results also demonstrate that HEMnDP cells represent a suitable cell model to study mechanisms regulating melanogenesis and antioxidant defence system in human pigmentation disorders.

Acknowledgments This work was financially supported by the Medical University of Silesia in Katowice (Grants No. KNW-2-002/D/4/N and KNW-1-015/K/4/0).

Conflict of interest The authors declare that they have no competing interests. The manuscript entitled "Effect of thioridazine on antioxidant status of HEMn-DP melanocytes", which all the listed authors have read and approved, has not been submitted elsewhere for publication, in whole or in part, and is permitted to be published in this journal.

Open Access This article is distributed under the terms of the Creative Commons Attribution 4.0 International License (http://creativecommons.org/licenses/by/4.0/), which permits unrestricted use, distribution, and reproduction in any medium, provided you give appropriate credit to the original author(s) and the source, provide a link to the Creative Commons license, and indicate if changes were made.

\section{References}

Arana GW (2000) An overview of side effects caused by typical antipsychotics. J Clin Psychiatry 61:5-11

Beaulieu JM, Gainetdinov RR (2011) The physiology, signaling, and pharmacology of dopamine receptors. Pharmacol Rev 63:182-217

Beberok A, Buszman E, Otręba M, Wrześniok D (2012) Impact of lomefloxacin on antioxidant enzymes activity in normal melanocytes HEMa-LP. Curr Issues Pharm Med Sci 25:426-429

Bickers DR, Athar M (2006) Oxidative stress in the pathogenesis of skin disease. J Invest Dermatol 126:2565-2575

Buj Alvarez I, Pifarré Paredero J, Idini E, Puigdevall Ruestes M (2007) Repercussions of the withdrawal of thioridazine. Actas Esp Psiquiatr $36: 183-186$

Busca R, Berlotto C, Ortonne JP, Ballotti R (1996) Inhibition of the phosphatidylinositol 3-kinase/p70(S6)-kinase pathway induces B16 melanoma cell differentiation. J Biol Chem 271:31824-31830

Cuevas S, Villar VA, Jose PA, Armando I (2013) Renal dopamine receptors, oxidative stress, and hypertension. Int J Mol Sci 14:1755317572

Drucker AM, Rosen CF (2011) Drug-induced photosensitivity: culprit drugs, management and prevention. Drug Saf 34:821-837
Frey BN, Andreazza AC, Kunz M, Gomes FA, Quevedo J, Salvador M, Gonçalves CA, Kapczinski F (2007) Increased oxidative stress and DNA damage in bipolar disorder: a twin-case report. Prog Neuropsychopharmacol Biol Psychiatry 31:283-285

Gil-Ad I, Shtaif B, Levkovitz Y, Dayag M, Zeldich E, Weizman A (2004) Characterization of phenothiazine-induced apoptosis in neuroblastoma and glioma cell lines: clinical relevance and possible application for brain-derived tumors. J Mol Neurosci 22:189-198

Hearing VJ (2011) Determination of melanin synthetic pathways. J Invest Dermatol 131:E8-E11

Hoogduijn MJ, Cemeli E, Ross K, Anderson D, Thody AJ, Wood JM (2004) Melanin protects melanocytes and keratinocytes against $\mathrm{H}_{2} \mathrm{O}_{2}$-induced DNA strand breaks through its ability to bind $\mathrm{Ca}^{2+}$. Exp Cell Res 294:60-67

Hu DN, Savage HE, Roberts JE (2002) Uveal melanocytes, ocular pigment epithelium, and Müller cells in culture: in vitro toxicology. Int J Toxicol 21:465-472

Iida M, Miyazaki I, Tanaka K, Kabuto H, Iwata-Ichikawa E, Ogawa N (1999) Dopamine D2 receptor-mediated antioxidant and neuroprotective effects of ropinirole, a dopamine agonist. Brain Res 838:5159

Kalyanaraman B (2013) Teaching the basics of redox biology to medical and graduate students: oxidants, antioxidants and disease mechanisms. Redox Biol 1:244-257

Kang S, Dong SM, Kim BR, Park MS, Trink B, Byun HJ, Rho SB (2012) Thioridazine induces apoptosis by targeting the PI3K/Akt/mTOR pathway in cervical and endometrial cancer cells. Apoptosis 17: 989-997

Kim SS, Kim MJ, Choi YH, Kim BK, Kim KS, Park KJ, Park SM, Lee NH, Hyun CG (2013) Down-regulation of tyrosinase, TRP-1, TRP2 and MITF expressions by citrus press-cakes in murine B16 F10 melanoma. Asian Pac J Trop Biomed 3:617-622

Kim DS, Kim SY, Park SH, Choi YG, Kwon SB, Kim MK, Na JI, Youn SW, Park KC (2005) Inhibitory effects of 4-n-butylresorcinol on tyrosinase activity and melanin synthesis. Biol Pharm Bull 12: 2216-2219

Kim HE, Lee SG (2013) Induction of ATP synthase $\beta$ by $\mathrm{H}_{2} \mathrm{O}_{2}$ induces melanogenesis by activating PAH and cAMP/CREB/MITF signaling in melanoma cells. Int J Biochem Cell Biol 45:1217-1222

Lamer V, Lipozencić J, Turcić P (2010) Adverse cutaneous reactions to psychopharmaceuticals. Acta Dermatovenerol Croat 18:56-67

Liu J, Choy KW, Chan LW, Leung TY, Tam PO, Chiang SW, Lam DS, Pang CP, Lai TY (2010) Tyrosinase gene (TYR) mutations in Chinese patients with oculocutaneous albinism type 1. Clin Experiment Ophthalmol 38:37-42

Llambrich A, Lecha M (2004) Photoinduced lichenoid reaction by thioridazine. Photodermatol Photoimmunol Photomed 20:108-109

Lundeberg L, El-Nour H, Mohabbati S, Morales M, Azmitia E, Nordlind $\mathrm{K}$ (2002) Expression of serotonin receptors in allergic contact eczematous human skin. Arch Dermatol Res 294:393-398

MacMorran WS, Krahn LE (1997) Adverse cutaneous reactions to psychotropic drugs. Psychosomatics 38:413-422

Mattila JP, Sabatini K, Kinnunen PK (2007) Oxidized phospholipids as potential novel drug targets. Biophys J 93:3105-3112

Min KJ, Seo BR, Bae YC, Yoo YH, Kwon TK (2014) Antipsychotic agent thioridazine sensitizes renal carcinoma Caki cells to TRAILinduced apoptosis through reactive oxygen species-mediated inhibition of Akt signaling and downregulation of Mcl-1 and c-FLIP(L). Cell Death Dis 5, e1063

Morak-Młodawska B, Jeleń M (2007) New biological properties of neuroleptic phenothiazines. Pol Merkur Lekarski 23:459-461

Nagel D, Spranger S, Vincendeau M, Grau M, Raffegerst S, Kloo B, Hlahla D, Neuenschwander M, Peter von Kries J, Hadian K, Dörken B, Lenz P, Lenz G, Schendel DJ, Krappmann D (2012) Pharmacologic inhibition of MALT1 protease by phenothiazines 
as a therapeutic approach for the treatment of aggressive $\mathrm{ABC}$ DLBCL. Cancer Cell 22:825-837

Nordlind K, Azmitia EC, Slominski A (2008) The skin as a mirror of the soul: exploring the possible roles of serotonin. Exp Dermatol 17: 301-311

Otręba M, Miliński M, Buszman E, Wrześniok D, Beberok A (2013) Hereditary hypomelanocytoses: the role of $P A X 3, S O X 10, M I T F$, SNAI2, KIT, EDN3 and EDNRB genes. Adv Hyg Exp Med 67: $1109-1118$

Otręba M, Rok J, Buszman E, Wrześniok D (2012) Regulation of melanogenesis: the role of cAMP and MITF. Adv Hyg Exp Med 66:3340

Otręba M, Wrześniok D, Beberok A, Rok J, Buszman E (2015) Melanogenesis and antioxidant defense system in normal human melanocytes cultured in the presence of chlorpromazine. Toxicol In Vitro 29:221-227

Ozeki H, Ito S, Wakamatsu K, Thody AJ (1996) Spectrophotometric characterization of eumelanin and pheomelanin in hair. Pigment Cell Res 9:265-270

Plonka PM, Passeron T, Brenner M, Tobin DJ, Shibahara S, Thomas A, Slominski A, Kadekaro AL, Hershkovitz D, Peters E, Nordlund JJ, Abdel-Malek Z, Takeda K, Paus R, Ortonne JP, Hearing VJ, Schallreuter KU (2009) What are melanocytes really doing all day long ...? Exp Dermatol 18:799-819

Rho SB, Kim BR, Kang S (2011) A gene signature-based approach identifies thioridazine as an inhibitor of phosphatidylinositol-3'kinase(PI3K)/AKT pathway in ovarian cancer cells. Gynecol Oncol 120:121-127

Richtand NM, Welge JA, Logue AD, Keck PE Jr, Strakowski SM, McNamara RK (2007) Dopamine and serotonin receptor binding and antipsychotic efficacy. Neuropsychopharmacology 32:17151726

Rok J, Otręba M, Buszman E, Wrześniok D (2012) Melanin-from melanocyte to keratinocyte, that is how melanin is transported within the skin. Ann Acad Med Siles 66:60-66

Rukmini MS, D'Souza B, D'Souza V (2004) Superoxide dismutase and catalase activities and their correlation with malondialdehyde in schizophrenic patients. Indian J Clin Biochem 19:114-118
Schallreuter KU, Kothari S, Chavan B, Spencer JD (2008) Regulation of melanogenesis - controversies and new concepts. Exp Dermatol 17: 395-404

Schallreuter KU, Salem MA, Gibbons NC, Martinez A, Slominski R, Lüdemann J, Rokos H (2012) Blunted epidermal L-tryptophan metabolism in vitiligo affects immune response and ROS scavenging by Fenton chemistry. Part 1: epidermal $\mathrm{H}_{2} \mathrm{O}_{2} / \mathrm{ONOO}(-)$-mediated stress abrogates tryptophan hydroxylase and dopa decarboxylase activities, leading to low serotonin and melatonin levels. FASEB J 26:2457-2470

Singh K, Kaur S, Kumari K, Singh G, Kaur A (2009) Alterations in lipid peroxidation and certain antioxidant enzymes in different age groups under physiological conditions. J Hum Ecol 27:143-147

Slominski AT, Zmijewski MA, Skobowiat C, Zbytek B, Slominski RM, Steketee JD (2012) Sensing the environment: regulation of local and global homeostasis by the skin's neuroendocrine system. Adv Anat Embryol Cell Biol 212:1-115

Sravani PV, Babu NK, Gopal KV, Rao GR, Rao AR, Moorthy B, Rao TR (2009) Determination of oxidative stress in vitiligo by measuring superoxide dismutase and catalase levels in vitiliginous and nonvitiliginous skin. Indian J Dermatol Venereol Leprol 75:268-271

Tolleson WH (2005) Human melanocyte biology, toxicology and pathology. J Environ Sci Health C Environ Carcinog Ecotoxicol Rev 23: $105-161$

Wakamatsu TH, Dogru M, Tsubota K (2008) Tearful reactions: oxidative stress, inflammation and eye diseases. Arq Bras Oftalmol 71:72-79

Wójcikowski J, Maurel P, Daniel WA (2006) Characterization of human cytochrome p450 enzymes involved in the metabolism of the piperidine-type phenothiazine neuroleptic thioridazine. Drug Metab Dispos 34:471-476

Wrześniok D, Beberok A, Otręba M, Buszman E (2013a) Modulation of melanogenesis and antioxidant defense system in melanocytes by amikacin. Toxicol In Vitro 27:1102-1108

Wrześniok D, Beberok A, Otręba M, Buszman E (2013b) Effect of streptomycin on melanogenesis and antioxidant status in melanocytes. Mol Cell Biochem 383:77-84

Wrześniok D, Otręba M, Beberok A, Buszman E (2013c) Impact of kanamycin on melanogenesis and antioxidant enzymes activity in melanocytes - an in vitro study. J Cell Biochem 114:2746-2752 